\title{
Gene therapy may not be as expensive as people think: challenges in assessing the value of single and short-term therapies
}

\section{SUMMARY}

At an upfront price of $\$ 2.125$ million, the one-time gene therapy onasemnogene abeparvovec for spinal muscular atrophy, a rare neuromuscular disorder that is usually fatal by 2 years of age if untreated, has been called the "most expensive drug ever." This flawed characterization raises important methodological and policy issues regarding valuation of high-cost treatments. We reviewed several other high-cost therapieswith a particular focus on hemophilia $A$ treatment-studied by the nonprofit Institute for Clinical and Economic Review (ICER). In ICER's summary report of 2 treatments for managing hemophilia $A$, published in this month's JMCP issue, the estimated \$15-\$18 million lifetime cost of factor VIII is characterized as "far too high," representing "a failure of competition [that] ... builds a platform for pricing of treatments ... that will only exacerbate these problems." Current literature indicates several factors underlying high factor VIII treatment cost (eg, historical pattern of innovation and lack of market competition) that may also drive the pricing dynamics of advanced therapies for other rare diseases.

When a treatment's price is driven high (or "distorted"), an economic principle known as "theory of the second best" suggests that market price becomes a poor estimate of social opportunity cost, and adjustments should be made for such distortions. In any case, a high-cost standard of care creates an opportunity for new technology to generate cost savings, providing an inducement for market entry. Recognizing that this potentially creates a tendency to produce price distortions for new treatments, ICER has attempted to apply some ad hoc adjustments.

However, challenges remain in creating a "level playing field" across different diseasemodifying or potentially curative innovations (eg, one-time therapy vs ongoing or lifelong treatment with repeated doses). While additional policy work is needed to address this dilemma, it would clearly be misleading to assume that gene therapies are inherently expensive. Rigorous economic evaluation of novel therapies requires careful comparison of lifetime cost and benefits vs standard of care, including adjustments for pricing distortions. Fortunately, economic theory suggests that we could adjust to this circumstance by using the social opportunity costs of interventions based on an appropriate variable cost-effectiveness threshold that would be higher for rare severe diseases.
Novel, innovative treatments, particularly those for rare diseases, are generally costly. Onasemnogene abepar- vovec (Zolgensma), a one-time gene therapy for spinal muscular atrophy (SMA), is frequently cited as "the most

\section{Author affiliations}

Louis P Garrison, Jr, PhD, and Boshen Jiao, $\mathrm{MPH}$, University of Washington, Seattle. Omar Dabbous, MD, Novartis Gene Therapies, Inc., Bannockburn, IL.

\section{AUTHOR CORRESPONDENCE:}

Louis P Garrison, Jr, 206.427.0798;

lgarrisn@uw.edu

J Manag Care Spec Pharm 2021;27(5):674-81

Copyright $@ 2021$, Academy of Managed Care Pharmacy. All rights reserved. expensive drug ever." Immediately following its approval by the US Food and Drug Administration in May 2019, a 
National Public Radio story affirmed this with the headline: "At \$2.1 Million, New Gene Therapy Is the Most Expensive Drug Ever." ${ }^{1}$ However, the article also (correctly) indicated that babies with the most severe form of the disorder (SMA type 1) typically do not live past their second birthdays. ${ }^{1}$

Characterizing this therapy as "the most expensive drug ever" is misleading. First, some drug therapies for other conditions are, in fact, more costly. At the extreme, we can consider the lifetime costs of factor VIII (FVIII) hemophilia A patients without inhibitors (antibodies that may render FVIII ineffective in coagulation) and those of patients with inhibitors who require prophylactic bypassing agents (BPAs). The US-based, private, nonprofit Institute for Clinical and Economic Review (ICER) has estimated the average costs over a lifetime of treatment for these patients to be between $\$ 15$ million and $\$ 100$ million, which is more than 3 times (and up to 20 times) the projected lifetime cost for a patient with SMA treated with onasemnogene abeparvovec..$^{2-6}$ Because onasemnogene abeparvovec is still a relatively new therapy, the actual lifetime cost for the patient is somewhat uncertain, although the availability of real-world data is growing. The durability of onasemnogene abeparvovec's clinical benefit is unknown: Since it is not curative, patients will require varying levels of supportive care.

The second reason is essentially a conflation of upfront cost with value (ie, "expensive" suggests "poor value for money"). To accurately assess treatment value, one must understand the return on a \$2.125-million upfront investment in a baby with SMA type 1, a calculation complicated by many factors, including the expected lifetime productivity of a patient with SMA treated with onasemnogene abeparvovec, downstream medical costs, and the likely spillover effects on caregivers and family members.

In extraordinary circumstances when specific individuals face great risk of imminent death, societies quickly spend tens of millions of dollars on lifesaving efforts (eg, the Thai boys trapped in the cave; the Chilean miners trapped underground). The US government has established guidelines for valuing the mortality impacts of federal programs based on the value of a statistical life at approximately $\$ 9.9$ million (range: \$4.6-\$15.0 million) ${ }^{?}$

These estimates are controversial and the focus of many publications. ${ }^{8,9}$ Ultimately, however, there is a consensus that cost comparisons should be done on a lifetime basis. Thus, it is misleading-and conceptually incorrect-to compare one-time gene therapies with yearly costs of other medicines, such as oncology drugs that often cost between $\$ 100,000$ and $\$ 250,000$ annually and may be used for several years..$^{10,11}$
While numerous hemophilia A gene therapies are under development, the prognosis for these patients with hemophilia A differs from those with SMA. Patients with hemophilia A who receive prophylactic BPAs or FVIII have near-normal life expectancy; the objective of gene therapy is to improve a patient's health-related quality of life. But the current standard of care would be considered a highcost comparator (ie, very costly and its cost-effectiveness has been questioned). ${ }^{12}$ How should cost-effectiveness analysis (CEA), as a component of health technology assessment, address these single and short-term therapies (SSTs), as ICER refers to them? ? $^{13,14}$

\section{The High Cost of Treating Hemophilia A}

If the value of a statistical life is approximately $\$ 9.9$ million, how have we come to pay tens of millions of dollars to treat patients with hemophilia A? ${ }^{7}$ Untreated, hemophilia A may cause spontaneous and traumatic bleeding, joint pain and damage, and can lead to disability and premature death. ${ }^{15}$ To prevent these outcomes, patients usually receive on-demand or prophylactic FVIII replacement therapy. ${ }^{15}$ Prophylactic FVIII is associated with better health outcomes compared with on-demand treatment. ${ }^{16}$

When replacement therapy was first introduced, FVIII was derived from human plasma. ${ }^{17}$ However, the advent of recombinant FVIII products has revolutionized hemophilia A management by eliminating the risk of bloodborne virus transmission. ${ }^{17}$ Nonetheless, shifting from a plasmaderived product to a recombinant product substantially increased costs. ${ }^{18,19}$ Also, a minority of hemophilia A patients will develop inhibitors and may receive either frequent, high-dosage FVIII to overcome them (immune tolerance therapy) or BPAs. ${ }^{20}$ In the United States, the annual costs of clotting factor treatments are approximately 3 to 5 times greater for those patients with inhibitors vs those without. ${ }^{21,22}$ In addition, the adoption of extended half-life FVIII continues to rise in the United States, further increasing costs. ${ }^{23}$

ICER assessed costs for patients with severe hemophilia A without a history of inhibitors. ${ }^{5,6}$ The treatment regimen in the control arm was prophylactic FVIII, based on the 2 most commonly used drugs: recombinant antihemophilic factor (Advate) and recombinant B-domain deleted antihemophilic factor, Fc fusion protein (Eloctate). ${ }^{5,6}$ For adult patients, the projected prophylactic FVIII medical costs over a patient's lifetime were approximately \$19 million (present value; Table 1). ${ }^{5,6}$ An earlier ICER report, which focused on patients with severe hemophilia A and a history 


\section{TABLE 1 Projected Costs Associated with Prophylactic FVIII or Bypassing Agent for Hemophilia A From Recent Literature}

\begin{tabular}{|c|c|c|c|c|c|}
\hline Author & Study population & Treatment & Time horizon & Age & Projected costs per patient (2019 USD)a \\
\hline \multirow{2}{*}{ ICER, $2018^{2}$} & \multirow{2}{*}{$\begin{array}{l}\text { Patients with severe } \\
\text { hemophilia A with } \\
\text { inhibitors }\end{array}$} & \multirow{2}{*}{$\begin{array}{l}\text { Prophylactic } \\
\text { BPAs }^{\text {b }}\end{array}$} & \multirow{2}{*}{ Lifetime } & $\begin{array}{l}\text { Model starting age: } \\
8.5 \text { years }\end{array}$ & $\begin{array}{l}\text { Drug costs: } \$ 93,725,959 \\
\text { Total medical costs: } \mathbf{\$ 1 0 3 , 4 7 3 , 8 0 0}\end{array}$ \\
\hline & & & & $\begin{array}{l}\text { Model starting age: } \\
37 \text { years }\end{array}$ & $\begin{array}{l}\text { Drug costs: } \$ 84,915,543 \\
\text { Total medical costs: } \mathbf{\$ 9 4 , 0 5 6 , 2 6 7}\end{array}$ \\
\hline $\begin{array}{l}\text { Earnshaw et al, } \\
2015^{24}\end{array}$ & $\begin{array}{l}\text { Patients with severe } \\
\text { hemophilia A with } \\
\text { inhibitors }\end{array}$ & $\begin{array}{c}\text { Prophylactic } \\
\text { BPAs }^{\mathrm{b}}\end{array}$ & Lifetime & $\begin{array}{l}\text { Model starting age: } \\
2.1 \text { months }\end{array}$ & Total medical costs: $\$ 46,554,604$ \\
\hline Zhou et al, $2020^{25}$ & $\begin{array}{l}\text { Patients with severe } \\
\text { hemophilia A } \\
\text { without inhibitors }\end{array}$ & $\begin{array}{l}\text { Prophylactic } \\
\text { FVIII }\end{array}$ & Lifetime & $\begin{array}{l}\text { Model starting age: } \\
1 \text { year }\end{array}$ & $\begin{array}{l}\text { Drug costs: } \$ 13,851,737 \\
\text { Total medical costs: } \mathbf{\$ 2 2 , 8 2 0 , 2 8 1}\end{array}$ \\
\hline Cook et al, $2020^{26}$ & $\begin{array}{l}\text { Patients with severe } \\
\text { hemophilia A } \\
\text { without inhibitors }\end{array}$ & $\begin{array}{c}\text { Prophylactic } \\
\text { FVIII }\end{array}$ & Lifetime & $\begin{array}{l}\text { Model starting age: } \\
30 \text { years }\end{array}$ & Total medical costs: $\$ 23,466,845$ \\
\hline \multirow{2}{*}{$\begin{array}{l}\text { Agboola et al, 2021; } \\
\text { Rind et al, } 2020 \\
\text { (ICER report) }\end{array}$} & \multirow{2}{*}{$\begin{array}{l}\text { Patients with severe } \\
\text { hemophilia A } \\
\text { without inhibitors }\end{array}$} & \multirow{2}{*}{$\begin{array}{l}\text { Prophylactic } \\
\text { FVIII }\end{array}$} & \multirow{2}{*}{ Lifetime } & $\begin{array}{l}\text { Model starting age: } \\
18 \text { years }\end{array}$ & $\begin{array}{l}\text { Drug costs: } \$ 18,269,000 \\
\text { Total medical costs: } \mathbf{\$ 1 8 , 7 2 2 , 0 0 0}\end{array}$ \\
\hline & & & & $\begin{array}{l}\text { Model starting age: } \\
1 \text { year }\end{array}$ & $\begin{array}{l}\text { Drug costs: } \$ 14,821,000 \\
\text { Total medical costs: } \mathbf{\$ 1 5 , 1 0 4 , 0 0 0}\end{array}$ \\
\hline Machin et al, $2018^{27}$ & $\begin{array}{l}\text { Patients with severe } \\
\text { hemophilia A } \\
\text { without inhibitors }\end{array}$ & $\begin{array}{c}\text { Prophylactic } \\
\text { FVIII }\end{array}$ & 10 years & $\begin{array}{l}\text { Model starting age: } \\
30 \text { years }\end{array}$ & Total medical costs: $\$ 1,766,381$ \\
\hline Croteau et al, $2019^{23}$ & $\begin{array}{l}\text { Patients with severe } \\
\text { hemophilia A } \\
\text { without inhibitors }\end{array}$ & $\begin{array}{c}\text { Prophylactic } \\
\text { FVIII }\end{array}$ & 1 year & $\begin{array}{l}\text { Median age: } \\
22 \text { years }\end{array}$ & $\begin{array}{l}\text { Costs of standard FVIII: } \$ 719,790 \\
\text { Costs of extended half-life FVIII: } \$ 785,846\end{array}$ \\
\hline Croteau et al, $2021^{28}$ & $\begin{array}{l}\text { Patients with severe } \\
\text { hemophilia A } \\
\text { without inhibitors }\end{array}$ & $\begin{array}{c}\text { Prophylactic } \\
\text { FVIII }\end{array}$ & 1 year & $\begin{array}{l}\text { Median age: } \\
25 \text { years }\end{array}$ & $\begin{array}{l}\text { Drug costs: } \$ 400,701-\$ 553,912 \\
\text { Total medical costs: } \mathbf{\$ 4 2 5 , 2 6 7 - \$ 5 7 5 , 3 4 1}\end{array}$ \\
\hline
\end{tabular}

${ }^{a}$ All costs were adjusted to 2019 USD using the Consumer Price Index.

${ }^{b}$ Recombinant factor VIla (NovoSeven), anti-inhibitor coagulant complex (FEIBA).

BPAs = bypassing agents; FEIBA = factor VIII inhibitor bypassing activity; FVIII = factor VIII; ICER=Institute for Clinical and Economic Review; USD=US dollar.

of inhibitors, projected that prophylactic BPAs cost more than $\$ 90$ million (present value) over a patient's lifetime (Table 1). ${ }^{2}$ ICER's estimates are a good representation of the current trend, since these assessments were recently conducted-one in 2018 and the latest in 2020. Prophylactic FVIII and BPAs cost much more than the $\$ 4$ million in projected lifetime medical costs for a patient with SMA type 1 treated with onasemnogene abeparvovec. ${ }^{3,4}$ In ICER's summary report, published in this issue, the estimated $\$ 15-\$ 18$ million-lifetime cost of FVIII was described as "far too high" in the United States, representing "a failure of competition." Also, the summary report adds that this "builds a platform for pricing of treatments and for potential cures that will only exacerbate these problems." ${ }^{5}$

A broad range of estimated costs for FVIII and BPAs are reflected in recent publications (Table 1). Earnshaw et al projected lifetime medical costs of $\$ 47$ million associated with prophylactic BPAs. ${ }^{24}$ Zhou et al and Cook et al estimated approximately $\$ 23$ million for lifetime medical costs associated with prophylactic FVIII. ${ }^{25,26}$ Machin et al projected 10-year medical costs of approximately \$2 million for prophylactic FVIII. ${ }^{27}$ Croteau et al calculated annual FVIII drug costs of more than $\$ 700,000,{ }^{23}$ although a more recent estimate by Croteau et al suggests a lower range of $\$ 400,000-\$ 550,000,{ }^{28}$ depending on alternative indicators of annual prophylactic use.

In addition to comparing the cost of onasemnogene abeparvovec with BPAs and FVIII, we also referenced recent ICER reports to determine the costs of nusinersen (Spinraza; an ongoing intrathecal treatment for SMA), ${ }^{4}$ other treatments for hemophilia $\mathrm{A}, 2,5,6$ and treatments for cystic fibrosis and hereditary angioedema. ${ }^{29,30}$ As summarized in 


\section{FIGURE 1 Projected Lifetime Medical Costs (2019 USD) Associated with Treatments for Spinal Muscular} Atrophy, Hemophilia A, Cystic Fibrosis, and Hereditary Angioedema Estimated by the Institute for Clinical and Economic Review $2,4-6,29,30$

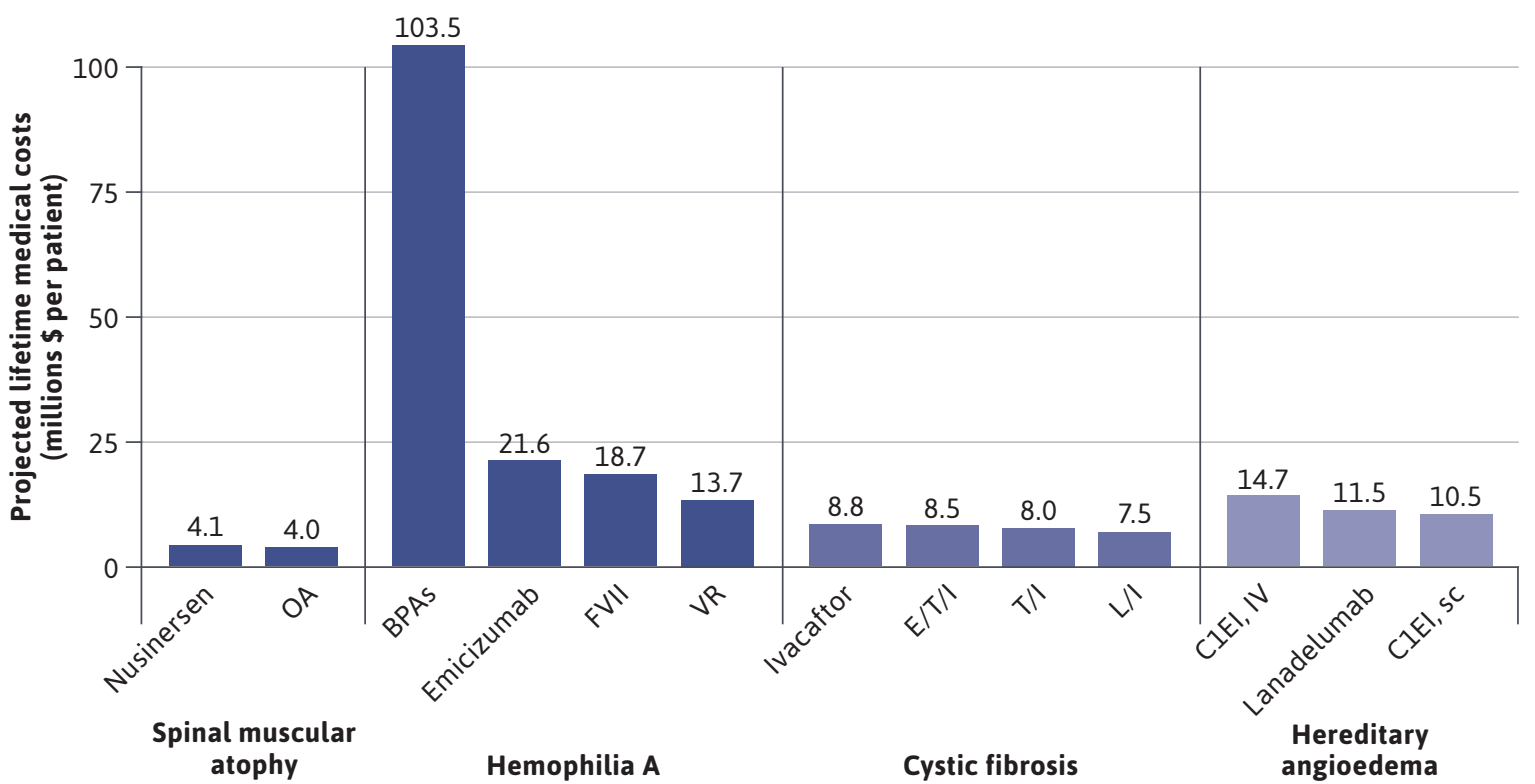

Notes: The costs of nusinersen were for patients with infantile-onset (type 1) spinal muscular atrophy; the costs of BPAs and emicizumab were for patients with

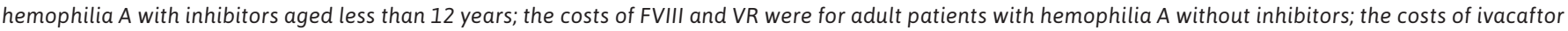

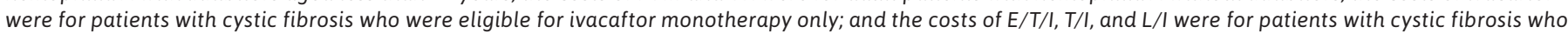
are homozygous for the F508del mutation. All costs were adjusted to 2019 USD using the Consumer Price Index.

$\mathrm{BPA}=$ bypassing agent; $\mathrm{CIEI}, \mathrm{IV}=\mathrm{Cl}$ esterase inhibitor, intravenous; $\mathrm{ClEI}, \mathrm{SC}=\mathrm{Cl}$ esterase inhibitor, subcutaneous; $\mathrm{E} / \mathrm{T} / \mathrm{I}=$ elexacaftor/tezacaftor/ivacaftor

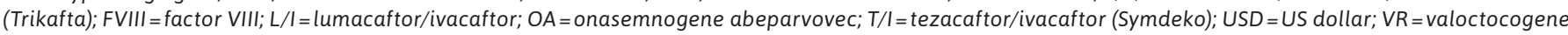
roxaparvovec.

Figure 1, lifetime medical costs for treatment with onasemnogene abeparvovec were less than those of nusinersen and substantially lower than treatment costs for hemophilia A (emicizumab-kxwh [Hemlibra]), cystic fibrosis (ivacaftor [Kalydeco] alone or combined with tezacaftor and/or elexacaftor or lumacaftor), and hereditary angioedema (plasma-derived C1 esterase inhibitors [Cinryze, Haegarda] and lanadelumab-flyo [Takhzyro]).

ICER also produced an analysis for valoctocogene roxaparvovec (Roctavian), an investigational gene therapy for hemophilia A, assuming an upfront price of \$2.5 million and projected total lifetime costs of \$14 million., Cook et al constructed a lifetime CEA model of valoctocogene roxaparvovec with an assumed upfront price of \$2 million and total medical cost of $\$ 17$ million. ${ }^{26}$ Both studies-assuming a decline in endogenous FVIII following valoctocogene roxaparvovec treatment-projected that valoctocogene roxaparvovec would be cost saving when compared with prophylactic FVIII. ${ }^{5,6,26}$
According to ICER's assessment, treatment of type 1 SMA with onasemnogene abeparvovec would yield, on average, 12.23 quality-adjusted life-years (QALYs; discounted), at a cost of approximately $\$ 300,000$ per QALY over a patient's lifetime. ${ }^{4}$ This number is significantly lower than the \$600,000-\$1 million per QALY for prophylactic FVIII ${ }^{5,6}$ and \$4-\$5 million per QALY for BPAs. ${ }^{2}$ Therefore, "the most expensive drug ever" is an objectively inaccurate label. Neither, however, do these figures imply that FVIII treatments are not cost-effective. Characterizing any treatment as "the most expensive" implies that its cost does not reflect the value of its health benefits.

Why are these costs so high? Our review of the literature suggests several potential factors. First, adoption of recombinant and high-purity plasma-derived clotting factors dramatically increased treatment costs. ${ }^{18,19,31-36}$ Technological advances (eg, recombinant methods, plasma collection and testing, fractionation, purification, viral inactivation) further increased prices. ${ }^{19,31,34}$ Second, there 
are few competitors in the hemophilia A clotting factor market, $18,19,35,36$ and less expensive biosimilars are not available. ${ }^{37}$ In addition, the large investment required is likely a barrier to entering these markets. ${ }^{19}$ Third, patients and health care providers are relatively insensitive to the price of clotting factors, since insurance covers most costs..$^{19,36-39}$ Fourth, government price regulation has been ineffective in controlling costs; price is often market-based, ${ }^{37}$ and the government does not impose price caps..$^{19}$ Although the 340B Drug Pricing Program covered comprehensive hemophilia treatment centers and aimed to reduce costs, manufacturers were able to adjust their "best price" to maintain greater $340 \mathrm{~B}$ prices..$^{18}$ Fifth, clotting factors have been consumed in high volumes,,$^{19,40,41}$ as a result of prophylactic use and increased confidence in the safety of recombinant products. ${ }^{18}$ Finally, manufacturers have implemented aggressive promotional strategies to maintain patient and provider loyalty to specific products, which has helped to preserve higher prices. ${ }^{19,39}$

\section{Cost-Effectiveness Analysis and the Theory of the Second Best}

A basic principle of economics is that activities should be pursued if marginal benefit (MB) exceeds marginal cost (MC), subject to an overall budget or affordability constraint. From a societal perspective, MC should be the social opportunity cost (ie, the value of the $\mathrm{MB}$ of the best alternative use of those resources). While we generally assume that competitive markets support this principle, departures from competitive conditions (eg, monopolistic behavior) may distort market prices so that they no longer approximate social opportunity cost.

The theory of the second best argues that if these distortions are present, comparisons of $\mathrm{MB}$ to $\mathrm{MC}$ based on market prices are insufficient to judge optimality. ${ }^{42}$ For analyses using the incremental cost-effectiveness ratio (MC/MB), analysts should adjust distorted market prices in their calculations to represent social opportunity cost.

The clotting factor market is likely subject to price distortions because of such factors as oligopoly, insurance subsidies, and tacit collusion, ${ }^{18,19,31,34,36-39,43}$ resulting in a market price potentially much greater than the social opportunity cost. Thus, we should assume that the first-best rule $(\mathrm{MB}>\mathrm{MC})$ no longer applies and using the distorted market price in an economic evaluation would lead to a faulty assessment. In a second-best world, analysts should employ a more complex analysis incorporating social opportunity costs in their evaluation. This issue has been raised by the US First and Second Panels on Cost-Effectiveness and
Health and Medicines, which noted that, in theory, societal CEAs should use "social marginal costs." ${ }^{44,45}$

ICER recognized and commented on this issue in the context of potentially curative SSTs; they considered several options, including capping the cost of standard care with FVIII or BPAs based on an external cost-effectiveness threshold (proposed range, $\$ 100,000-\$ 150,000$ ), which would reduce the projected savings of gene therapies, other things being equal. ${ }^{46}$ While the clotting factor costs might be inconsistent with this range, recent literature has argued for a variable threshold that may be greater for severe diseases (ie, a greater cost-effectiveness threshold may be justified for diseases such as hemophilia or severe Alzheimer disease). Using the latter as an example, Lakdawalla and Phelps recommended that a cost-effectiveness threshold of 5 times the average annual per capita consumption $(\$ 50,000-\$ 80,000)$, implying that a range of $\$ 250,000-\$ 400,000$ per QALY could be appropriate..$^{47}$ But in the case of hemophilia, even a capped price based on this higher threshold range would be far below the cost of prophylactic FVIII and BPAs reported by ICER.

\section{ICER's Efforts to Address Second-Best Considerations}

The theory of the second best implies that conventional CEAs need to be modified when new products enter the market at distorted prices. ICER recognized this issue and consulted with many economic experts on how best to address it. ICER understood that comparing high-impact SSTs with a long-term therapy that has a distorted high price would give a false sense of cost savings. ${ }^{14}$ ICER also contends that it is unfair for conventional CEAs to allocate all economic surplus from the cost-offset to SST innovators. ${ }^{14}$ Unlike long-term therapy, which is expected to lose economic surplus after generic competition enters the market, an SST would be less likely to face such competition. Thus, ICER considered 2 hypothetical "shared-savings" scenarios, in which society retains a share of the surplus that results from cost-offsets. ${ }^{14}$ In the first scenario, ICER automatically assigns $50 \%$ of the cost-offsets to the health system; in the second scenario, the cost-offsets (ie, the costs of comparator) are capped at $\$ 150,000$ per year. ${ }^{14}$

Although ICER's approach may lead to fairer comparisons, the issue is not fully resolved, since social opportunity costs are not reflected in either scenario. The first approach is arbitrary, since the costs of comparators were simply reduced by $50 \%$. The second approach might bring comparators' costs closer to social opportunity costs, but the $\$ 150,000$ per year cap of the cost-offset depends on 
this figure, reflecting the appropriate cost-effectiveness threshold. Some economists have argued for a variable, and sometimes greater, threshold for severe diseases. ${ }^{7,47}$

ICER had previously proposed another approach, in which they created a hypothetical patent expiry time point (12 years after launch) when the economic surplus would transfer from the SST manufacturer to the health system. ${ }^{13}$ It has, however, abandoned this approach ${ }^{14}$ commenting (without a detailed explanation) that SSTs may have cost-offsets many years after patent expiry and that fixing this problem in cure proportion models would not be technically possible. ${ }^{14}$

Another fundamental issue is that SSTs and long-term therapies interact differently with respect to the economic surplus, patent life, and value-based price-as in the case of a long-term therapy that offers the same cure as an SST-but must be taken repeatedly over the patient's remaining lifetime. ${ }^{48}$ In theory, the patent of such repeated-dose cures and SSTs should expire after approximately 12 years. ${ }^{49-52}$ Ideally, there would be parity-a level playing field-between repeated-dose cures and SSTs in the value-based price framework, but it is difficult to satisfy the following 3 conditions: (1) the one-time valuebased price for a patient initiating SST in the first year of patent life should be the same as that for a patient initiating SST in the last year of patent life; (2) the value-based price (per dose) for a patient initiating a repeated-dose cure in the first year of patent life should be the same as that for a patient initiating it in the last year of patent life; and (3) the value-based price for a patient initiating SST in the first year of patent life should be nearly equal to the present discounted cost of 12 years of the repeated-dose cure. Providing clear and stable signals to developers via value-based price is important for them to optimize their investment decisions, thereby promoting dynamic efficiency (ie, moving toward optimal research and development for the health system).

Using stylized examples, Towse and Fenwick examined several challenges that arise in comparing one-time cures with repeated-dose cures, including the consideration of fixed patent life. ${ }^{48}$ Their analysis concluded that innovative financial risk-sharing arrangements may be required to level the playing field. From the perspective of applying conventional CEAs in a second-best world, we believe that more methodological work and empirical measurement are needed to address these challenges.

\section{Conclusions}

While stating that the treatments discussed herein are inexpensive would be disingenuous, it is clearly misleading to label a gene therapy, such as onasemnogene abeparvovec for SMA, as "the most expensive ever" based on upfront cost alone and without comparison with the benefits. Rigorous, comprehensive CEAs are integral to the accurate value assessment of any therapy. From a scientific standpoint, value assessment should be made based on costs and health benefits over patients' lifetimes. Furthermore, appropriate assessment from a societal perspective would account for existing distortions, insofar as we are operating in a second-best world. Fortunately, economic theory suggests that we could adjust to this circumstance by using the social opportunity costs of interventions based on an appropriate cost-effectiveness threshold that would vary and be higher for rare, severe diseases.

\section{DISCLOSURES}

The research reported in this Viewpoints article was funded by Novartis Gene Therapies, Inc. Garrison and Jiao were paid by Novartis Gene Therapies, Inc., to conduct this research. Garrison has also received consulting fees from BioMarin, Inc, and UniQure. Dabbous is a full-time employee of Novartis Gene Therapies, Inc., and holds Novartis stock and stock options.

\section{ACKNOWLEDGMENTS}

The authors thank David Wolff, MS, and Michael A. Nissen, ELS, both of Novartis Gene Therapies, Inc. (Bannockburn, IL), for medical writing and editing support in the development of this article. The authors also thank Sandra P. Reyna, MD, of Novartis Gene Therapies, Inc., and Jennifer Sung, of Novartis, for their critical reviews of this article.

\section{REFERENCES}

1. Stein R. At \$2.1 million, new gene therapy is the most expensive drug ever. Transcript. All Things Considered. NPR. May 24, 2019. Accessed March 22, 2021. https://www.npr.org/sections/ health-shots/2019/05/24/725404168/ at-2-125-million-new-gene-therapy-isthe-most-expensive-drug-ever

2. Rind D, Steuten L, Agboola F, et al. Emicizumab for hemophilia A with inhibitors: effectiveness and value. Final evidence report. Institute for Clinical and Economic Review. April 16, 2018. Accessed March 22, 2021. https://icer. org/wp-content/uploads/2020/10/ ICER Hemophilia Final Evidence Report 041618.pdf

3. Malone DC, Dean R, Arjunji R, et al. Cost-effectiveness analysis of using onasemnogene abeparvocec (AVXS101) in spinal muscular atrophy type 1 patients. J Mark Access Health Policy. 2019;7(1):1601484. doi:10.1080/20016689.2 019.1601484 
4. Ellis AG, Thokala P, Mickle K, et al. Spinraza ${ }^{\circledR}$ and Zolgensma ${ }^{\circledR}$ for spinal muscular atrophy: effectiveness and value. Final evidence report. Institute for Clinical and Economic Review. April 3, 2019. Accessed March 22, 2021. https:// icer.org/wp-content/uploads/2020/10/ ICER SMA Final Evidence

Report_110220.pdf

5. Agboola F, Rind DM, Walton SM, Herron-Smit S, Quach D, Pearson SD. The effectiveness and value of emicizumab and valoctocogene roxaparvovec for the management of hemophilia A without inhibitors: a summary from the Institute for Clinical and Economic Review's New England Comparative Effectiveness Public Advisory Council. J Manag Care Spec Pharm. 2021;27(5):667-73.

6. Rind D, Walton S, Agboola F, et al. Valoctocogene roxaparvovec and emicizumab for hemophilia A: effectiveness and value. Draft evidence report. Institute for Clinical and Economic Review. August 26, 2020. Accessed March 22, 2021. https:// icer.org/wp-content/uploads/2020/10/ ICER Hemophilia-A Draft-EvidenceReport_082620-1.pdf

7. Garrison LP, Jackson T, Paul D, Kenston M. Value-based pricing for emerging gene therapies: the economic case for a higher cost-effectiveness threshold. J Manag Care Spec Pharm. 2019;25(7):793-99. doi:10.18553/ jmcp.2019.18378

8. Viscusi WK. Best estimate selection bias in the value of a statistical life. J Benefit Cost Anal. 2018;9(2):205-46. doi:10.1017/bca.2017.21

9. Viscusi WK. Reference-dependence effects in benefit assessment: beyond the WTA-WTP dichotomy and WTA-WTP ratios. J Benefit Cost Anal. 2015;6(1):187206. doi:10.1017/bca.2015.3

10. Mailankody S, Prasad V. Five years of cancer drug approvals: innovation, efficacy, and costs. JAMA Oncol. 2015;1(4):539-40. doi:10.1001/ jamaoncol.2015.0373

11. Howard DH, Bach PB, Berndt ER, Conti RM. Pricing in the market for anticancer drugs. J Econ Perspect. 2015;29(1):139-62. doi:10.1257/jep.29.1.139
12. Pearson SD, Ollendorf DA, Chapman RH. New cost-effectiveness methods to determine value-based prices for potential cures: what are the options? Value Health. 2019;22(6):656-60. doi:10.1016/j.jval.2019.01.012

13. Chapman R, Kumar V, Samur S, Zaim R, Segel C, Pearson S. Value assessment methods and pricing recommendations for potential cures: a technical brief. Institute for Clinical and Economic Review. August 6, 2019. Accessed March 22, 2021. https://icer. org/wp-content/uploads/2020/10/ Valuing-a-Cure-Technical-Brief.pdf

14. Institute for Clinical and Economic Review. Adapted value assessment methods for high-impact "single and short-term therapies" (SSTs). November 12, 2019. Accessed March 22, 2021. https://icer.org/ wp-content/uploads/2020/10/ICER SST_FinalAdaptations_111219.pdf

15. Centers for Disease Control and Prevention (CDC). What is Hemophilia? May 12, 2020. Available at: https://www. cdc.gov/ncbddd/hemophilia/facts.html. Accessed September 9, 2020

16. Collins PW, Blanchette VS, Fischer K, et al. Break-through bleeding in relation to predicted factor VIII levels in patients receiving prophylactic treatment for severe hemophilia A. J Thromb Haemost. 2009;7(3):413-20. doi:10.1111/j.1538-7836.2008.03270.x

17. Franchini M. Plasma-derived versus recombinant factor VIII concentrates for the treatment of haemophilia A: recombinant is better. Blood Transfus. 2010;8(4):292-96. doi:10.2450/2010.0067-10

18. Rogoff EG, Guirguis HS, Lipton RA, et al. The upward spiral of drug costs: a time series analysis of drugs used in the treatment of hemophilia. Thromb Haemost. 2002;88(4):545-53.

19. Guirguis HS, Rogoff EG. Strategies and impacts of new drug introduction: hemophilia treatment. J Health Care Finance. 2004;31(1):1-12.
20. Meeks SL, Batsuli G. Hemophilia and inhibitors: current treatment options and potential new therapeutic approaches. Hematology Am Soc Hematol Educ Program. 2016;2016(1):657-62.

21. Guh S, Grosse SD, McAlister S, Kessler CM, Soucie JM. Healthcare expenditures for males with haemophilia and employer-sponsored insurance in the United States, 2008. Haemophilia. 2012;18(2):268-75. doi:10.1111/j.1365-2516.2011.02692.x

22. Guh S, Grosse SD, McAlister S, Kessler CM, Soucie JM. Health care expenditures for Medicaid-covered males with haemophilia in the United States, 2008. Haemophilia. 2012;18(2):276-83. doi:10.1111/j.1365-2516.2011.02713.x

23. Croteau SE, Cheng D, Cohen AJ, et al. Regional variation and cost implications of prescribed extended half-life factor concentrates among U.S. Haemophilia Treatment Centres for patients with moderate and severe haemophilia. Haemophilia. 2019;25(4):668-75. doi:10.1111/hae.13758

24. Earnshaw SR, Graham CN, McDade CL, Spears JB, Kessler CM. Factor VIII alloantibody inhibitors: cost analysis of immune tolerance induction vs. prophylaxis and on-demand with bypass treatment. Haemophilia. 2015;21(3): 310-19. doi:10.1111/hae.12621

25. Zhou Z-Y, Raimundo K, Patel AM, et al. Model of short- and long-term outcomes of emicizumab prophylaxis treatment for persons with hemophilia A. J Manag Care Spec Pharm. 2020;26(9):1109-20. doi:10.18553/jmcp.2020.19406

26. Cook K, Forbes SP, Adamski K, Ma JJ, Chawla A, Garrison LP. Assessing the potential cost-effectiveness of a gene therapy for the treatment of hemophilia A. J Med Econ. 2020;23(5):501-12. doi:10.1080/ 13696998.2020 .1721508

27. Machin N, Ragni MV, Smith KJ. Gene therapy in hemophilia A: a cost-effectiveness analysis. Blood Adv. 2018;2(14):1792-98. doi:10.1182/ bloodadvances.2018021345 
28. Croteau SE, Cook K, Sheikh L, et al. Health care resource utilization and costs among adult patients with hemophilia A on factor VIII prophylaxis: an administrative claims analysis. J Manag Care Spec Pharm. 2021;27(3):316-26. doi:10.18553/ jmcp.2021.27.3.316

29. Tice J, Kuntz K, Wherry K, et al. Modulator treatments for cystic fibrosis: effectiveness and value. Institute for Clinical and Economic Review. December 16, 2019. Accessed March 22, 2021. https://icer.org/wp-content/ uploads/2020/08/ICER CF MAP 121619.pdf

30. Institute for Clinical and Economic Review. Prophylaxis for hereditary angioedema with lanadelumab and $\mathrm{C} 1$ inhibitors: effectiveness and value. June 29, 2018. Accessed March 22, 2021. https://icer.org/ wp-content/uploads/2020/10/ICER HAE_MAP_062918.pdf

31. Aledort LM. Economics of hemophilia care. Haemostasis. 2000;30(6):333-36. doi:10.1159/000054151

32. Aledort LM. Factor VIII inhibitors. Immune tolerance induction: is it cost effective? We know too little. Semin Thromb Hemost. 2000;26(2):189-93. doi:10.1055/s-2000-9822

33. Berntorp E. Why prescribe highly purified factor VIII and IX concentrates? Vox Sang. 1996;70(2):61-68. doi:10.1111/j.1423-0410.1996.tb01295.x

34. Kletter SD, Rankin PJ. Cost trends in the treatment for hemophilia: another view. Thromb Haemost. 2002;88(4):542-44.

35. Smith SD. Million dollar miracles. Minn Med. 2006;89(4):30-35, 51.

36. Aledort LM. Can costs of hemophilia products be curtailed? Not as we do business today! Thromb Haemost. 2002;88(4):541.
37. Ahle S. The high price of hemophilia. ASH Clinical News. February 1, 2020. Accessed September 21, 2020. https:// www.ashclinicalnews.org/spotlight/ feature-articles/high-price-hemophilia/

38. Young D. GAO suggests Medicare make separate payments for clotting factors, delivery. Am J Health Syst Pharm. 2003;60(8):741. doi:10.1093/ajhp/60.8.741a

39. Kucab P, Stepanyan KD, Fugh-Berman A. Direct-to-consumer marketing to people with hemophilia. PLoS Med. 2016;13(6):e1001996. doi:10.1371/ journal.pmed.1001996

40. Gater A, Thomson TA, Strandberg-Larsen M. Haemophilia B: impact on patients and economic burden of disease. Thromb Haemost. 2011;106(3):398-404. doi:10.1160/ TH11-03-0193

41. Majumdar S, Ostrenga A, Latzman RD, et al. Pharmacoeconomic impact of obesity in severe haemophilia children on clotting factor prophylaxis in a single institution. Haemophilia. 2011;17(4):717-18. doi:10.1111/j.1365-2516.2010.02462.x

42. Lipsey RG, Lancaster K. The general theory of second best. Rev Econ Stud. 1956;24(1):11-32. doi:10.2307/2296233

43. Nauenberg E, Sullivan SD. Firm behavior in the U.S. market for factor VIII: a need for policy? Soc Sci Med. 1994;39(12):1591-603. doi:10.1016/0277-9536(94)90073-6

44. Neumann PJ, Sanders GD, Russell LB, Siegel JE, Ganiats TG. Cost-Effectiveness in Health and Medicine. 2nd ed. Oxford University Press; 2016.

45. Weinstein MC, Russell LB, Gold MR, Siegel JE. Cost-Effectiveness in Health and Medicine. Oxford University Press; 1996.
46. Institute for Clinical and Economic Review. 2020-2023 Value Assessment Framework. January 31, 2020. Updated October 23, 2020. Accessed March 22, 2021. http://icer.org/wp-content/ uploads/2020/10/ICER_2020_2023_ VAF 102220.pdf

47. Lakdawalla DN, Phelps CE. Health technology assessment with risk aversion in health. J Health Econ. 2020;72:102346. doi:10.1016/j.jhealeco.2020.102346

48. Towse A, Fenwick E. Uncertainty and cures: discontinuation, irreversibility, and outcomes-based payments: what is different about a one-off treatment? Value Health. 2019;22(6):677-83. doi:10.1016/j. jval.2019.03.013

49. Grabowski H, Long G, Mortimer R, Boyo A. Updated trends in US brand-name and generic drug competition. J Med Econ. 2016;19(9):836-44. doi:10.1080/13696998.2 016.1176578

50. Wang B, Liu J, Kesselheim AS. Variations in time of market exclusivity among top-selling prescription drugs in the United States. JAMA Intern Med. 2015;175(4):635-37. doi:10.1001/ jamainternmed.2014.7968

51. Kesselheim A. Determinants of market exclusivity for prescription drugs in the United States. The Commonwealth Fund. September 13, 2017. Accessed March 22, 2021. https://www.commonwealthfund. org/publications/journal-article/2017/ sep/determinants-market-exclusivityprescription-drugs-united

52. US Food and Drug Administration. Exclusivity and generic drugs: what does it mean? Accessed March 22, 2021. https://www.fda.gov/media/111069/ download 